\title{
Testing common hornbeam (Carpinus betulus L.) acetylated with the Accoya method under industrial conditions
}

\author{
Fanni Fodor ${ }^{(1)}$, \\ Chiel Lankveld ${ }^{(2)}$ \\ Róbert Németh ${ }^{(1)}$
}

\begin{abstract}
Introduction
Acetylation is a chemical modification process that has been studied by scientists around the world for almost 90 years (Fuchs 1928). A pilot plant was built in the Netherlands in 2004, and after 3 years a large-scale commercial facility was constructed in 2007 and the production of acetylated wood began. Acetylated wood is now specified and used globally in residential and commercial applications.

During acetylation, acetic anhydride is 'used as a dehydrating agent. The hydroxyl groups are replaced by acetyl groups, which results in dimensionally stable wood. There are many characteristics of wood
\end{abstract}

\begin{abstract}
Hornbeam wood is known for its high density, hardness, toughness, and wear resistance, but due to its low durability (Class 5 according to EN 350), limited wood quality, and rather small sawmill yield, it is mainly utilized as firewood today. The potential for hornbeam to be used as solid, high-quality wood material exists if its durability and dimensional stability can be increased. Hornbeam boards were acetylated under industrial conditions and tests were carried out to evaluate the treatability of this wood species by acetylation. In this study, the examination of physical, mechanical, and durability properties of acetylated hornbeam wood are described and compared to untreated hornbeam and to acetylated beech, which has a similar anatomical structure to hornbeam. Acetylated hornbeam was also compared to acetylated radiata pine, which is the main product of Accsys Technologies. These comparisons include the determination of the equilibrium moisture content, density, dimensional stability, accelerated checking, color change, water uptake, decay resistance, compression strength, modulus of rupture (MOR), modulus of elasticity (MOE), impact bending strength, Janka hardness, Brinell hardness, and impact bending strength. The aim of this project is the creation of a new product thereby widening the usage of this species.
\end{abstract}

Keywords: Hornbeam, Acetylation, Accoya, Physical Properties, Mechanical Properties, Durability, Color (like extractives, sample parameters, moisture, density, permeability and wood quality) and treatment settings (like catalysts, purity of the anhydride, initial moisture content, temperature, pressure, etc.) that influence the final products' properties. After acetylation, the samples are taken for chemical quality assurance and the weight percentage gain is calculated (WPG).

The dimensional stability or anti-swelling efficiency (ASE) is produced by wood cell wall bulking. At 20\% WPG, an impressive $70 \%$ ASE is found. This means that wood modified to a WPG of $20 \%$ will shrink and swell by about one-fourth of the amount exhibited with the same unmodified wood,
(1) Institute of Wood Science, Simonyi Karoly Faculty of Engineering, Wood Sciences and Applied Arts, University of Sopron, Bajcsy-Zs. u. 4. H-9400 Sopron (Hungary); (2) Accsys Technologies PLC group, 6802 CC Arnhem (Netherlands)

@ Fanni Fodor (fodor.fanni@phd.uni-sopron.hu)

Received: Jan 17, 2017 - Accepted: Sep 25, 2017

Citation: Fodor F, Lankveld C, Németh R (2017). Testing common hornbeam (Carpinus betulus L.) acetylated with the Accoya method under industrial conditions. iForest 10: 948-954. doi: 10.3832/ifor2359-010 [online 2017-12-19]

Communicated by: Giacomo Goli which is a significant improvement. However, under normal service conditions the actual absolute swelling and shrinkage would be far less since wood in service is never oven dried for two days at $103^{\circ} \mathrm{C}$ and then immersed continuously in water for five days (Hill 2006). Cell wall bulking leads to smaller equilibrium moisture content (EMC) and swelling.

These phenomena were experienced by many researchers. The decrease in EMC was observed in acetylated beech, poplar, Scots pine, radiata pine (Bongers \& Beckers 2003, Németh et al. 2010), and black locust (Németh et al. 2010).

The increased WPG enables better ASE in acetylated radiata pine, southern pine, ponderosa pine, hard maple, walnut, elm, cativo, eucalyptus (Rowell 1984, Ozmen 2007), beech (Militz 1991a), pine (Larsson \& Simonson 1994, Ramsden et al. 1997), rubberwood (Rafidah et al. 2006), poplar, willow (Ozmen 2007), black locust (Németh et al. 2010), and flakeboards (Rowell \& Plackett 1988). Nevertheless, this is not applicable to every species. For example, red oak and teak had weak ASE despite the high WPG (Rowell 1984).

As the weight percentage increases, density also increases in acetylated beech, poplar, Scots pine, radiata pine (Bongers \& Beckers 2003, Németh et al. 2010), and 
black locust (Németh et al. 2010).

In the cases of poplar and black locust ${ }^{3}$ wood, Németh et al. (2010) observed that the lightness $\left(L^{*}\right)$ decreased, the red hue $\left(a^{*}\right)$ increased, and the yellow hue $\left(b^{*}\right)$ de${ }^{6}$ creased after acetylation.

Acetylated material is far more resistant against any biological attack. It is the WPG rather than $\mathrm{OH}$ substitution that determines the degree of decay resistance (Hill et al. 2003). Many studies have been performed using laboratory pure culture tests, sterile and non-sterile laboratory soil burial tests, and long-term outdoor exposure stests that showed the optimal WPG above which hardly any microbial degradation (usually weight loss) of the wood occurs. It ${ }^{8}$ cannot be extrapolated which WPG is sufficient against any biological attack in wood species, but it can be concluded that the higher the level of acetylation, the higher the durability will be. Multiple scientific papers have proven a direct link between ${ }^{2}$ acetyl content and wood durability (Peterson \& Thomas 1978, Imamura \& Nishimoto 1987, Beckers et al. 1994, Ohkoshi et al. 1999, Suttie et al. 1999, Larsson et al. 2000), but there are also other influential factors like water uptake, density, anatomy, etc. According to Militz (1991b), beech resisted brown and white rot fungi at 20\% WPG. It needs $12 \%$ WPG against Coriolus ${ }_{3}^{3}$ versicolor, 20\% WPG against Poria placenta, $17 \%$ WPG against Coniophora puteana and Gloeophyllum trabeum, and 10\% WPG ${ }^{6}$ against soft rot decay (Beckers et al. 1994). Acetylation increases the weight of wood, which also increases wood density giving it higher compression strength and hardness properties. This phenomenon is more prominent in saturated wood as the "acetylation-induced moisture content reduction in turn increases the tensile strength, the modulus of rupture (MOR), is and the modulus of elasticity (MOE). Some cell wall degradation may occur due to the enhanced heat and pressure as well as the presence of acetic acid (Hill 2006). According to the scientific literature, it is unclear how acetylation affects mechanical properties; some scientists report an increase in strength (Dreher et al. 1964, Youngquist et al. 1986, Larsson \& Simonson 1994, Ramsden et al. 1997, Németh et al. 2010), some report unaffected properties (Dreher et al. 1964, Larsson \& Tillman 1989, Larsson \& Simonson 1994, Papadopoulos \& Tountziarakis 2011), and others a slight decrease in strength (Narayanamurti \& Handa 1953, Dreher et al. 1964, Hon 1996, Papadopoulos 2008, Papadopoulos \& Tountziarakis 2012). It should be noted that these results were obtained in lab scale tests and were not optimized on industrial scale.

Hornbeam (Carpinus betulus L.), which is ${ }^{6}$ known for its high density, hardness, toughness and wear-resistance, was chosen for this study. It is mainly used as fire${ }^{69}$ wood (50-60\% in Hungary) because of its limited durability and defects like twisted grain and ridged trunk (which gives small
${ }^{72}$ yield). If its durability and dimensional stability can be improved, it has the potential to be used for high added value applications, such as decking and fencing. To our knowledge, no scientific paper concerning the acetylation of hornbeam wood exists.

The aim of this study was to perform a variety of tests on untreated and acetylated hornbeam wood (from the same area of origin) and offer conclusions and suggestions regarding the feasibility of this product. If the results are promising, the process can be optimized for hornbeam; thus, a new product group for outdoor usage can be developed and the usage of the wood species can be widened as well.

\section{Material and methods}

\section{Wood material}

Twenty pieces of edged and air-dry boards were ordered from a Hungarian sawmill. Their dimensions were $28 \times 160 \times$ $2500 \mathrm{~mm}^{3}(\mathrm{~T} \times \mathrm{W} \times \mathrm{L})$. The wood was from the southwest part of Hungary. Half of the boards were put aside as untreated control specimens and the other half were transported to Accsys Technologies (Netherlands).

\section{Acetylation}

Before acetylation, the dimensions were measured with a measuring tape $( \pm 0.5$ $\mathrm{mm})$ and a caliper $( \pm 0.01 \mathrm{~mm})$. The moisture content was determined with an electrical resistance moisture meter equipped with insulated electrodes according to EN13183-2 (2002). The weight was specified using a laboratory scale $( \pm 0.01 \mathrm{~g})$. The boards' density and moisture content had low variation, which was ideal for the acetylation process. Prior to acetylation, the boards were pre-dried at the sawmill (ca. 30-40\%) following standard protocols, then dried with a convection dryer to a $12 \%$ moisture content. The acetylation process took place under industrial conditions.

\section{Weight percentage gain (WPG)}

There were no twists or cracks observed on the boards after acetylation. The WPG of ten boards was calculated.

\section{Physical properties}

The EMC and density were measured in every test according to DIN-52183 (1977) and DIN-52182 (1976), respectively. The shrinkage $(\beta)$ and anti-swelling efficiency (ASE) were defined according to DIN-52184 (1979) using 50 samples in each case.

The maximum water uptake after 49 days was determined on 50 samples in each case according to EN-927-5 (2007). The absorption and desorption cycle were examined in a floating and submersion test for 144 hours according to a research paper of Van Acker et al. (2014). A silicone sealant (Ceresit CS24 ${ }^{\circledast}$ universal silicone, Killich, (zech Republic) was used to seal the edges.

The color was expressed in CIE $L^{*} a^{*} b^{*}$ and $\mathrm{CIE} L^{*} C^{*} h$ color system. The color of one untreated and two treated pieces of wood were measured using a CM-26ood ${ }^{\circledR}$ spectrophotometer (Konica Minolta, Tokyo, Japan) with the help of Spectramagic NX program. The colorimeter's sensor head was $3 \mathrm{~mm}$. The color was measured and calculated based on the $\mathrm{D}_{65}$ illuminant and $10^{\circ}$ standard observer. Color measurements were done on the side surfaces with 30 measurement points on each side. The color change for depth was determined in 8 cycles. A cycle here refers to the following: after the color measurement of a surface, the surface was planed (approx. 1-1.5 $\mathrm{mm}$ ). This process was repeated 8 times and allowed the color change and homogeneity to be examined across the surface and the depth.

\section{Durability}

A non-industrial accelerated checking test was performed according to a house method to determine how prone the wood is to develop checks. Before the test, $20 \mathrm{~cm}$ long pieces were cut from each board (10 untreated and 10 acetylated) and each was examined for splits or checks. The surfaces were marked to indicate the bark (B) and heart $(H)$ sides. Thereafter, the samples were submerged in water at room temperature for 24 hours. Immediately after the water stage, the samples were placed in an oven at $40^{\circ} \mathrm{C}$ and the temperature was increased to as high as $103{ }^{\circ} \mathrm{C}$ until constant mass was achieved. The pieces were observed for checks and splits on the surface after drying.

Fungi resistance was determined according to EN-113 (1996) where the samples were exposed to Coniophora puteana and Poria placenta brown rot fungi, and Coriolus versicolor white rot fungus for 16 weeks. The culture medium was prepared from malt agar (malt extract agar 1.05398.0500, Kenilworth, Merck, NJ, USA). There were 11 Kolle flasks with reference samples for each fungus, with one untreated and one acetylated sample, and there were 2-4 flasks with virulence control specimens.

\section{Mechanical properties}

The compression strength parallel to the grain was determined according to DIN52185 (1976) using 50 samples in each case. The bending strength and MOE were measured on dry and water-saturated specimens (50 samples in each case) according to DIN-52186 (1978). When the specimen was put in the test machine, the loading head pressed the tangential face of the sample so that it was perpendicular to the annual rings.

The impact bending strength was determined according to DIN-52189-1 (1981) using 50 samples in each case. The test piece was put in the Charpy impact test machine so that the hammer encountered the radial section and knocked through the tangential section. The specimens all broke into 
Tab. 1 - Physical properties of untreated and acetylated hornbeam, beech and radiata pine; values in brackets are standard deviations. Literature data: (MB): Molnár \& Bariska (2002); (AT): Accsys Technologies (Netherlands); (W): Wagenführ (2007).

\begin{tabular}{|c|c|c|c|c|c|c|c|}
\hline \multirow{2}{*}{ Property } & \multirow{2}{*}{ Parameter } & \multicolumn{2}{|l|}{ Hornbeam } & \multicolumn{2}{|l|}{ Beech } & \multicolumn{2}{|c|}{ Radiata pine } \\
\hline & & Acetylated & Control & Acetylated & Control & Acetylated & Control \\
\hline \multirow{2}{*}{$\begin{array}{l}\text { Moisture } \\
\text { content (\%) }\end{array}$} & Fiber saturation point & $24(2.3)$ & $37(1.9)$ & - & $32-35^{\mathrm{MB}}$ & - & - \\
\hline & Equilibrium at $20^{\circ} \mathrm{C} 65 \%$ & $3(0.3)$ & $10(0.5)$ & - & - & - & - \\
\hline \multirow{3}{*}{$\begin{array}{l}\text { Density } \\
\left(\mathrm{kg} \mathrm{m}^{-3}\right)\end{array}$} & Dried & $801(66.3)$ & 689 (15.9) & - & $680^{w}$ & . & $400^{w}$ \\
\hline & Conditioned & $823(53.6)$ & $761(53.5)$ & $800^{\text {AT }}$ & $720^{w}$ & $510^{A T}$ & $510^{w}$ \\
\hline & Saturated & $982(58.2)$ & $942(35.5)$ & - & $1070^{w}$ & - & $800^{w}$ \\
\hline \multirow{3}{*}{$\begin{array}{l}\text { Shrinkage } \\
\text { (\%) }\end{array}$} & Radial & $1.17(0.47)$ & $6.46(0.67)$ & $1.3^{\mathrm{AT}}$ & $5.9^{\mathrm{AT}}$ & $0.7^{\mathrm{AT}}$ & $2.3^{w}$ \\
\hline & Tangential & $2.04(0.83)$ & $10.86(0.80)$ & $2.2^{\mathrm{AT}}$ & $12.9^{\mathrm{AT}}$ & $1.5^{\mathrm{AT}}$ & $4.5^{w}$ \\
\hline & Longitudinal & $0.32(0.20)$ & $0.42(0.30)$ & - & $0.3^{\mathrm{MB}}$ & - & $0.3^{w}$ \\
\hline \multicolumn{2}{|c|}{ Max. water uptake $\left(\mathrm{g} \mathrm{m}^{-2}\right)$} & 4559 (1035) & $5513(1137)$ & $5600^{\mathrm{AT}}$ & - & $23442^{\text {AT }}$ & - \\
\hline
\end{tabular}

two pieces during the tests.

Janka hardness was determined in every anatomical direction, on dry and water-saturated specimens according to ISO-3350 (1975) with different dimensions. The specimens were $50 \mathrm{~mm}$ wide, $50 \mathrm{~mm}$ long and only $25 \mathrm{~mm}$ thick instead of the desired 50 $\mathrm{mm}$ due to the thinness of the available ${ }^{9}$ material. This difference in size can affect the results because the big loading head caused the samples to crack more easily. 2 There were 50 untreated samples, but only 25 acetylated samples.

Brinell hardness was determined in every anatomical direction, on dry and water-saturated specimens according to EN-1534 (2010) with different dimensions (50 samples in each case). Similarly, the specimens were $50 \mathrm{~mm}$ wide, $50 \mathrm{~mm}$ long, and only 25 $\mathrm{mm}$ thick instead of $50 \mathrm{~mm}$ due to the thinness of the available material. In this case, the sample size does not affect the results because of the small indentation. The indentation points were distributed randomly. $500 \mathrm{~N}$ was applied during the test as it is a European wood species.

\section{Results and discussion}

\section{Weight percentage gain (WPG)}

The WPG ranged between $13.6 \%$ and $16.5 \%$, having an average of $15.3 \%$. The WPG level indicated that the wood was successfully impregnated.

\section{Equilibrium moisture content and density}

Hornbeam was unable to absorb as much ${ }^{36}$ moisture in an acetylated state as it can in a natural state. EMC values decreased by $70 \%$ after acetylation and the fiber saturation point (FSP) was 35\% lower. Due to weight gain, density changed by $16 \%$ in the dry state, $8 \%$ in the conditioned state, and $24 \%$ in the saturated state (Tab. 1 ).

\section{Shrinkage, dimensional stability}

Tangential shrinkage was $41 \%$ greater than radial shrinkage in untreated samples and $43 \%$ greater in treated samples (Tab. 1 ). The shrinkage values of acetylated samples "were lower than shrinkage values of untreated samples; the values were $81 \%, 82 \%$, and $24 \%$ lower in the tangential, radial, and longitudinal directions, respectively. This is related to the increased ASE, which was measured from the saturated to dried state, and from the conditioned $\left(20^{\circ} \mathrm{C} 65 \%\right)$ to dried state, which resulted in $81 \%$ and $88 \%$ ASE, respectively.

\section{Water uptake}

In connection with the moisture content reduction, the acetylated specimens had $17 \%$ lower water uptake/loss values (Tab. 1). Fig. 1 shows the rate of water uptake (a) and water loss (b) after 144 hours.

Compared to acetylated beech and acetylated radiata pine, acetylated hornbeam had $18 \%$ and $80 \%$ lower water uptake after 49 days, respectively (Tab. 1).

This change of hygroscopicity indicates that acetylated hornbeam has lower hysteresis and lower sorption isotherms than natural hornbeam (Engelund et al. 2010). In order to prove this hypothesis, further tests need to be carried out regarding the sorption behavior of acetylated hornbeam. This can be useful in applications like parquet, decking, or façades where the wood is exposed to water and frequently changing humidity.

\section{Accelerated checking}

Due to forced moisture and temperature changes, the untreated hornbeam samples
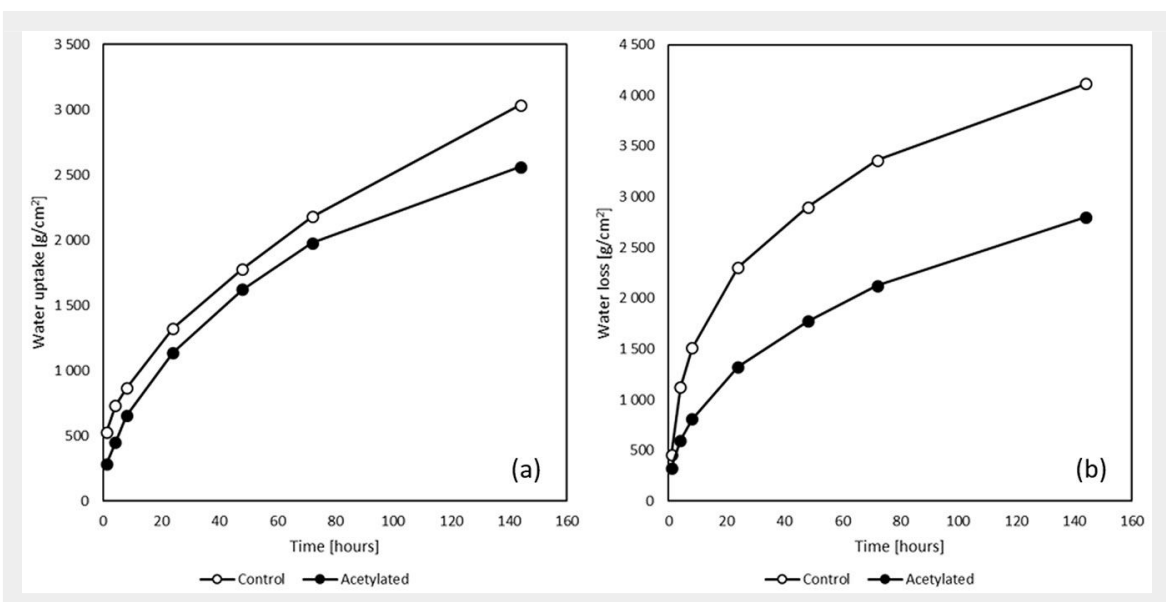

Fig. 1 - Water uptake and loss of untreated and acetylated hornbeam after 144 hours. discolored, warped, cracked, and developed internal checks and fiber cell collapses. None of the untreated samples remained intact; cracks appeared on both sides as well as on the end grain. On the contrary, the acetylated samples were more dimensionally stable; only a few hairline cracks appeared because of the accelerated desorption. There were no detectable differences in appearance between the heart and bark side of the board.

\section{Color measurements}

The darkening of acetylated wood highly depends on the reaction conditions and the catalyst used (pyridine, dimethylformamide, etc.), and of course on the wood species (chemical structure, permeability) itself (Rowell 1983). Hornbeam is a highly permeable, diffuse-porous species that is suitable for acetylation.

Natural hornbeam has wavy grain because of its growing pattern, but this look is more prominent when it is acetylated. Besides this, there were stains because of condensed water on the boards as a result of drying, but these were removed by the first planing. During the acetylation process, the reagent could fully penetrate the wood. There was no envelope effect, just 1-2 mm thick, darker crusting where the acetyl content is the highest. Internal cracks were observed on the acetylated 


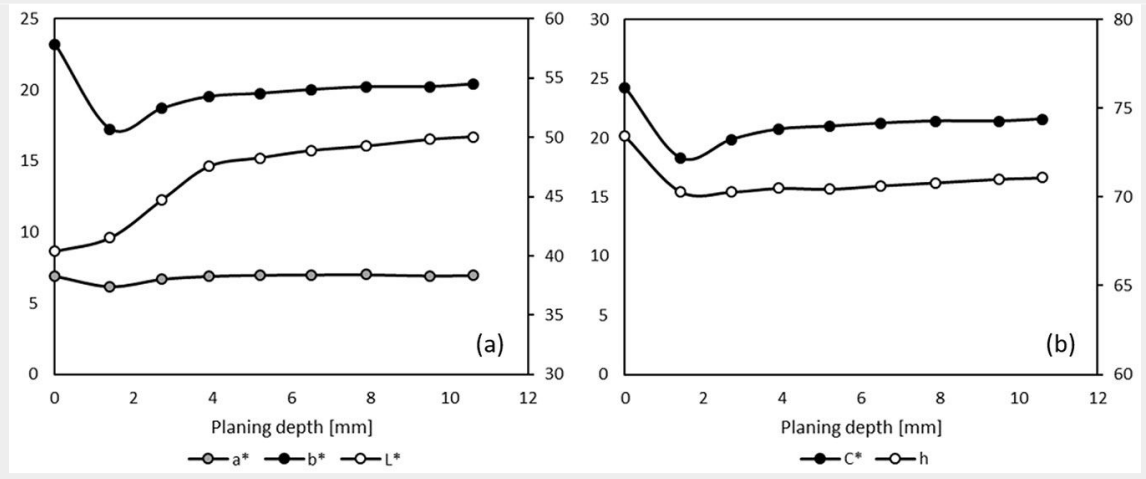

Fig. 2 - Color properties of acetylated hornbeam surfaces in different depths. $\left(L^{*}\right)$ : lightness; $\left(a^{*}\right)$ : red hue; $\left(b^{*}\right)$ : yellow hue; $(h)$ : hue; $\left(C^{*}\right)$ : chroma.

Tab. 2 - Color properties of acetylated hornbeam, hornbeam and some similar wood species (Molnár 2004). ( $\left.L^{*}\right)$ : lightness; $\left(a^{*}\right)$ : red hue; $\left(b^{*}\right)$ : yellow hue; $(h)$ : hue; $\left(C^{*}\right)$ : chroma; $\left(\Delta E^{*}\right)$ : color difference of each species is compared to acetylated hornbeam.

\begin{tabular}{lcccccc}
\hline Wood species & $\boldsymbol{L}^{*}$ & $\boldsymbol{a}^{*}$ & $\boldsymbol{b}^{*}$ & $\boldsymbol{h}$ & $\boldsymbol{C}^{*}$ & $\boldsymbol{A E}^{*}$ \\
\hline Acetylated hornbeam & 50.05 & 6.97 & 20.42 & $71.08^{\circ}$ & 21.58 & - \\
Hornbeam & 76.78 & 3.69 & 20.44 & $79.79^{\circ}$ & 20.77 & 26.93 \\
Beech (Molnár 2004) & 71.08 & 9.09 & 19.28 & $64.75^{\circ}$ & 21.31 & 21.16 \\
Walnut (Molnár 2004) & 51.30 & 6.21 & 14.32 & $66.55^{\circ}$ & 15.60 & 6.27 \\
Mutenye (Molnár 2004) & 52.00 & 9.38 & 22.99 & $67.80^{\circ}$ & 24.82 & 4.02 \\
\hline
\end{tabular}

Tab. 3 - Weight loss of untreated and acetylated samples exposed to wood-decay fungi for 16 weeks. Values are means \pm standard deviation.

\begin{tabular}{lllr}
\hline Fungus & Vessel & Sample & Weight loss (\%) \\
\hline $\begin{array}{l}\text { Coniophora } \\
\text { puteana }\end{array}$ & Virulence & Control & $45.64 \pm 3.68$ \\
& Reference & Control & $18.58 \pm 1.07$ \\
& & Acetylated & $0.84 \pm 0.17$ \\
Poria & & Control & $20.78 \pm 1.54$ \\
placenta & Virulence & Control & $21.19 \pm 6.61$ \\
& Reference & Acetylated & $0.20 \pm 0.21$ \\
Coriolus & & Control & $34.00 \pm 1.91$ \\
versicolor & Virulence & Control & $32.66 \pm 2.09$ \\
& Reference & Acetylated & $0.83 \pm 0.12$ \\
\hline
\end{tabular}

samples as they were taken from the end of the boards where wood moisture des${ }^{3}$ orption is more intensive.

The test results show that going deeper into the wood, the surface color becomes more homogenous ( $\Delta E^{*}$ decreases) even though the sticker marks fade away only after 4-5 mm (Fig. 2). After acetylation, the lightness decreased, the red hue increased, and the hue decreased. As shown in Tab. 2 , it gained a greyish-brown color, which differs from natural hornbeam or beech, but is similar to walnut (Juglans spp.) or mutenye (Guibourtia arnoldiana - Molnár 2004).

\section{Fungi resistance}

Acetylation greatly improved the fungi resistance of hornbeam, as can be seen in Tab. 3. It lost less than $1 \%$ of its weight when exposed to three different fungi. When the untreated specimen was accompanied by an acetylated specimen, the untreated sample lost less weight than the virulence samples because of the reagent's presence in the flask. In some cases, the fungi could not degrade the wood material because of the appearance of mold; these samples were excluded from the results. In the case of Poria placenta, 4 out of 9 acetylated samples showed negative weight loss, which were changed to zero according to standard.

Coniophora puteana attacks both softwood and hardwood but has a preference for conifers. In the case of virulence samples, the fungi successfully decayed the material, but when the samples were mixed, the reference controls were more prone to mold attack.

Poria placenta attacks primarily conifers, but the weight loss values (20.78\%) indicate that the test was successful (in the case of conifers it would have been around 35$40 \%)$. The mold is also present in many instances, and the deviation is larger than in the cases of the other two fungi.

Coriolus versicolor attacks primarily broadleaved species, which explains the small deviation and the scarce appearance of mold (which could not hinder the decaying process). In this case, there is only a small difference between the virulence and reference untreated samples.

\section{Compression strength parallel to the grain}

Due to acetylation, hornbeam gained a harder and denser structure, which provided $43 \%$ higher compression strength properties. As seen in Tab. 4, its structure is still less homogenous than the untreated wood, resulting in higher deviation in the results. During the test, a greater number of samples were cloven due to the denser structure.

\section{MOR and MOE}

During the bending test of the dry samples, the untreated and acetylated samples gave different fractures. Most of the samples broke on the outer side where tension stress was induced. In some cases, the sample had skewed grain, which resulted in weaker bending strength $(<100 \mathrm{MPa})$. The difference in strength and flexibility is also reflected in the way the samples

Tab. 4 - Strength and elasticity properties of untreated and acetylated hornbeam, beech and radiata pine; values are means \pm standard deviation. Literature data: (MB): Molnár \& Bariska (2002); (AT): Accsys Technologies (Netherlands); (W): Wagenführ (2007).

\begin{tabular}{|c|c|c|c|c|c|c|c|}
\hline \multirow{2}{*}{\multicolumn{2}{|c|}{ Property }} & \multicolumn{2}{|l|}{ Hornbeam } & \multicolumn{2}{|l|}{ Beech } & \multicolumn{2}{|l|}{ Radiata pine } \\
\hline & & Acetylated & Control & Acetylated & Control & Acetylated & Control \\
\hline \multicolumn{2}{|c|}{ Compression strength parallel to grain $\left(\mathrm{N} \mathrm{mm}^{-2}\right)$} & $84.0 \pm 6.6$ & $59.0 \pm 4.3$ & - & $62^{\mathrm{MB}}$ & - & $51^{w}$ \\
\hline \multirow{2}{*}{ Modulus of rupture $\left(\mathrm{N} \mathrm{mm}^{-2}\right)$} & Conditioned & $173.0 \pm 25.2$ & $144.0 \pm 9.8$ & $114^{\mathrm{AT}}$ & $127^{\mathrm{AT}}$ & $39^{\mathrm{AT}}$ & $78^{w}$ \\
\hline & Saturated & $141.0 \pm 15.2$ & $73.0 \pm 6.4$ & $107^{\text {AT }}$ & $60^{\mathrm{AT}}$ & - & - \\
\hline \multirow[t]{2}{*}{ Modulus of elasticity $\left(\mathrm{kN} \mathrm{mm}^{-2}\right)$} & Conditioned & $15.4 \pm 1.5$ & $15.4 \pm 1.2$ & $12.15^{\mathrm{AT}}$ & $13.03^{\mathrm{AT}}$ & $8.79^{\mathrm{AT}}$ & $11^{\mathrm{w}}$ \\
\hline & Saturated & $14.1 \pm 1.4$ & $10.4 \pm 1.0$ & $11.68^{\mathrm{AT}}$ & $7.81^{\mathrm{AT}}$ & - & - \\
\hline \multicolumn{2}{|l|}{ Impact bending strength $\left(\mathrm{kJ} \mathrm{m}^{-2}\right)$} & $159.0 \pm 37.0$ & $84.0 \pm 10.8$ & - & $100^{M B}$ & $50^{\text {AT }}$ & $94^{w}$ \\
\hline
\end{tabular}


broke: the untreated samples had brittle fractures while the acetylated samples had stiff fractures (Fig. 3a). It took more time to bend the saturated untreated hornbeam samples than it did to bend the treated 'ones, because unsaturated untreated hornbeam became very soft, which leads to weaker bending strength and smaller MOE (Fig. 3b). Meanwhile, the acetylated samples did not absorb as much water, so their properties did not decrease as much (Tab. 4). After acetylation, the MOR of dry and saturated samples increased by $20 \%$ and $93 \%$, respectively. The MOE of saturated samples increased by $36 \%$.

\section{Impact bending strength}

Due to the increased density and hardness, hornbeam had $88 \%$ higher impact bending strength after acetylation. This is also reflected in the way the samples broke - untreated hornbeam had brittle, clean breaks while acetylated hornbeam had stiff, splintery fractures after impact. The treated material tends to have an inhomogeneous structure and sometimes lower dynamic loading properties because of the cell wall degradation caused by acetylation. Hornbeam tends to have a twisted or wavy grain, which needs to be taken into account during sample production. These wood defects are caused by natural growth and not hornbeam-specific settings used in the acetylation process, which can explain the high deviation of the results (Tab. 4).

\section{:Janka hardness}

The Janka hardness of the tangential surface was $9 \%$ higher than in tangential direction in both untreated and acetylated samples. After saturation, this difference increased to $26 \%$ for untreated samples and decreased to $4 \%$ for acetylated samples. However, cracks tend to appear across the pith rays when the tangential surface is tested.

After acetylation, the tangential and radial surfaces' hardness increased by $55 \%$ 8 and $56 \%$, respectively, whereas in the satu-
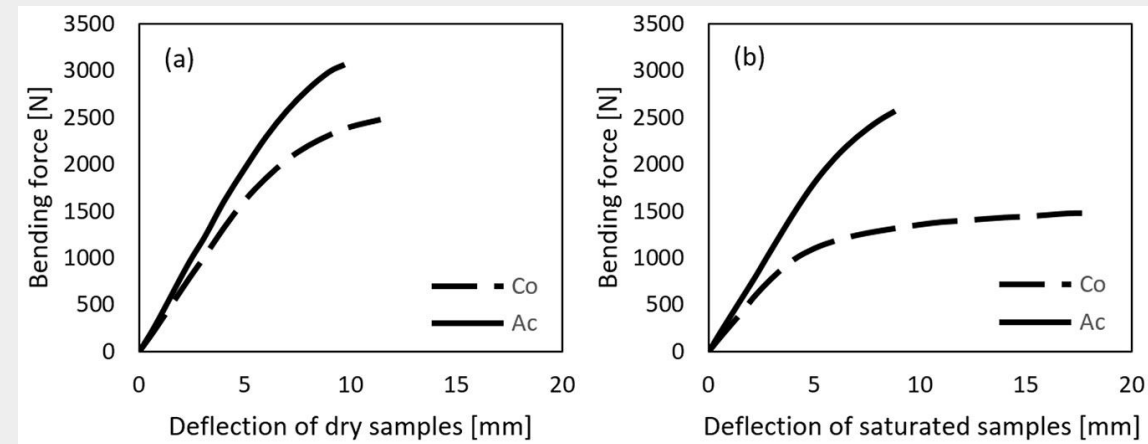

Fig. 3 - Fracture diagram of control (Co) and acetylated (Ac) hornbeam samples according to bending tests.
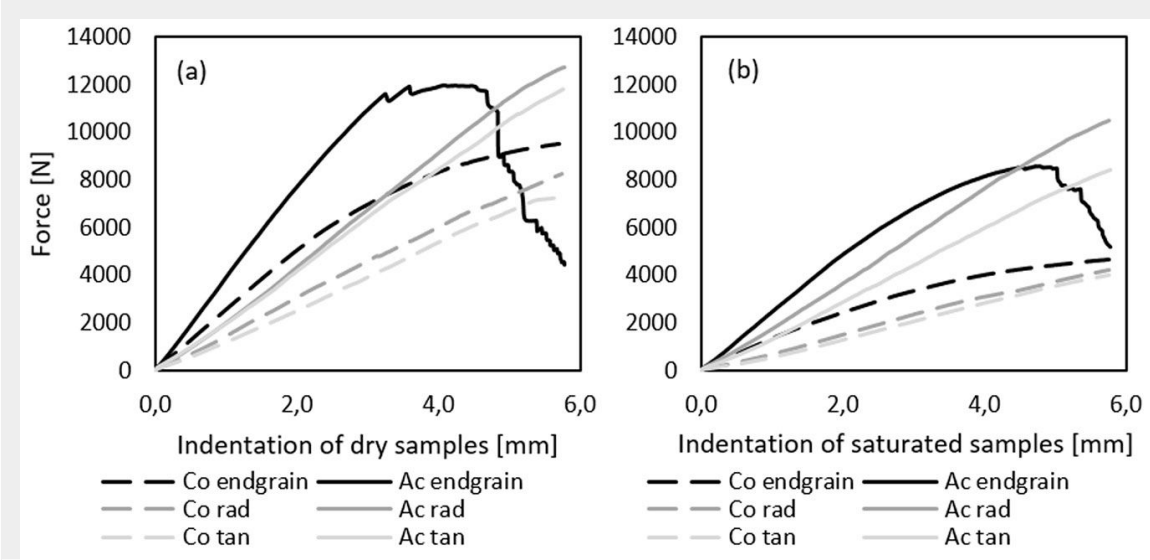

Fig. 4 - Force-indentation diagrams of Janka hardness tests. Control (Co) and acetylated (Ac) samples.

rated samples, these increased by $154 \%$ and ${ }^{60}$ Sults. As a side note, Fig. 4 shows the maxi$111 \%$, respectively (Fig. 4, Tab. 5). The radial mum force to have a tendency above 10-12 surface hardness of untreated samples de- $\mathrm{kN}$.

creased by $46 \%$ after saturation and the ra-

dial surface hardness decreased by $49 \%$. As ${ }^{\circ}$ Brinell hardness

for the acetylated samples, the same val- The Brinell hardness of the tangential surues decreased by $27 \%$ and $16 \%$, respectively face was $28 \%$ higher than the radial surface (Tab. 5).

${ }_{66}$ in the acetylated samples and $13 \%$ higher in

During the Janka hardness test of the end the untreated samples. After saturation, grain, the acetylated samples broke; those this difference decreased to $25 \%$ for the measurements are not included in the re- ${ }^{9}$ acetylated samples and $7 \%$ for the un-

Tab. 5 - Hardness properties of untreated and acetylated hornbeam, beech and radiata pine. Values are means \pm standard deviation. Literature data: (MB): Molnár \& Bariska (2002); (AT): Accsys Technologies (Netherlands); (W): Wagenführ (2007);

\begin{tabular}{|c|c|c|c|c|c|c|c|}
\hline \multirow{2}{*}{ Property } & & \multicolumn{2}{|l|}{ Hornbeam } & \multicolumn{2}{|l|}{ Beech } & \multicolumn{2}{|l|}{ Radiata pine } \\
\hline & & Acetylated & Control & Acetylated & Control & Acetylated & Control \\
\hline \multirow{3}{*}{$\begin{array}{l}\text { Janka hardness (conditioned) } \\
\left(\mathrm{N} \mathrm{mm}^{-2}\right)\end{array}$} & Radial & $114 \pm 17.9$ & $73 \pm 4.8$ & $79^{\mathrm{AT}}$ & $71^{\mathrm{AT}}$ & $41^{\text {AT }}$ & $28^{\mathrm{AT}}$ \\
\hline & Tangential & $124 \pm 21.4$ & $80 \pm 6.8$ & - & - & $42^{\text {AT }}$ & $28^{\text {AT }}$ \\
\hline & End grain & - & $95 \pm 7.3$ & $107^{\mathrm{AT}}$ & $84^{\mathrm{AT}}$ & $66^{\text {AT }}$ & $36^{A T}$ \\
\hline \multirow{3}{*}{$\begin{array}{l}\text { Janka hardness (saturated) } \\
\left(\mathrm{N} \mathrm{mm}^{-2}\right)\end{array}$} & Radial & $83 \pm 10.9$ & $39 \pm 2.9$ & - & - & - & - \\
\hline & Tangential & $105 \pm 15.3$ & $41 \pm 5.7$ & - & - & - & - \\
\hline & End grain & - & $46 \pm 3.5$ & - & - & - & - \\
\hline \multirow{3}{*}{$\begin{array}{l}\text { Brinell hardness (conditioned) } \\
\left(\mathrm{N} \mathrm{mm}^{-2}\right)\end{array}$} & Radial & $39 \pm 5.6$ & $26 \pm 2.4$ & - & $34^{\mathrm{MB}}$ & - & $13^{w}$ \\
\hline & Tangential & $50 \pm 9.1$ & $29 \pm 2.7$ & - & $34^{\mathrm{MB}}$ & - & $13^{w}$ \\
\hline & End grain & $101 \pm 12.7$ & $67 \pm 10.4$ & - & $72^{\mathrm{MB}}$ & - & - \\
\hline \multirow{3}{*}{$\begin{array}{l}\text { Brinell hardness (saturated) } \\
\left(\mathrm{N} \mathrm{mm}^{-2}\right)\end{array}$} & Radial & $32 \pm 4.7$ & $14 \pm 1.2$ & - & - & - & - \\
\hline & Tangential & $40 \pm 7.8$ & $15 \pm 1.5$ & - & - & - & - \\
\hline & End grain & $74 \pm 15.8$ & $30 \pm 3.1$ & - & - & - & - \\
\hline
\end{tabular}



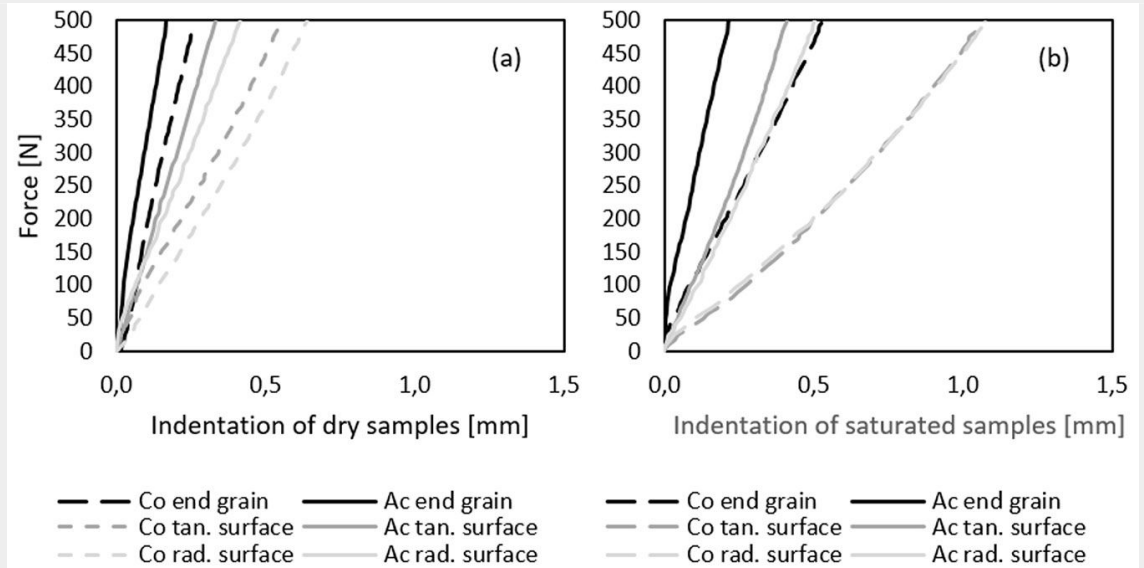

Fig. 5 - Force-indentation diagrams of Brinell hardness tests of control (Co) and acetylated $(A c)$ samples.

treated samples (Fig. 5).

After acetylation, the hardness values in${ }^{3}$ creased by $49 \%, 68 \%$ and $51 \%$ on the radial, tangential and end grain surface, respectively. With the saturated samples, the ${ }^{6}$ hardness values were $124 \%, 163 \%$, and $145 \%$ higher on the radial, tangential and end grain surface compared to natural hornbeam. The hardness of untreated samples decreased after saturation by $46 \%, 48 \%$, and $55 \%$ on the radial, tangential surface and end grain, respectively. As for the acetylated samples, the same values decreased by $18 \%, 19 \%$ and $26 \%$, respectively. 15 The high deviation in the results indicates inhomogeneity within the wood, but this can be explained by not hornbeam-specific sacetylation settings and the relatively small testing surface used during the Brinell hardness test (Tab. 5).

\section{Conclusions}

During the acetylation process, the cell walls of hornbeam became bulked due to the reaction between the hydroxyl groups of the cell wall and the acetic anhydride. Acetyl groups replaced the $\mathrm{OH}$ groups, ${ }^{3}$ which are responsible for the swelling and shrinkage of wood. As a result, hornbeam became less sensitive to moisture than it had been before. This is confirmed by our results, as the EMC, FSP, shrinking rate, and water uptake decreased and the ASE increased.

Acetylated samples showed a lower tendency to crack than natural hornbeam, ${ }^{3}$ which can also be explained by the bulking effect.

Due to acetylation, hornbeam's color darkened, became less homogenous, and developed a wavy figure. According to the color measurement, lightness $\left(L^{*}\right)$ decreased, red hue $\left(a^{*}\right)$ increased, while the yellow hue $\left(b^{*}\right)$ remained unchanged, the hue $(h)$ slightly increased and the chroma ${ }^{s}\left(C^{*}\right)$ slightly increased. Thus, the color turned a more reddish, grayish brown, similar to the color of walnut.

Acetylation prevented all three fungi species from attacking hornbeam, which in its natural state is a non-durable wood species (Class 5 according to EN-350 1994). After being exposed to fungi for 16 weeks, the treated samples' weight loss was below $1 \%$, which makes it a very durable material (Class 1 according to EN-350 1994). The presence of the acetylated material also had an impact on the reference samples, as fungi decayed these less than the virulence specimens.

It is difficult to state clearly how acetylation affects the mechanical properties of every wood species because there are many mechanisms that take place. On one hand, the capability of wood to absorb moisture decreases, which can influence the mechanical properties positively; also, the properties do not weaken as drastically as in the case of untreated wood during soaking. The density also increases as a result of the weight percentage gain. On the other hand, as the wood swells because of the acetyl groups, there will be fewer fibers in the cross section, which can decrease the mechanical properties. If the right settings are used for each wood species, the positive and negative effects can be kept in balance or tilted in the positive direction depending on the field of use and the properties to be improved. In the case of hornbeam wood, every mechanical property increased, which is very promising even though there were many instances of high variation in the results. Acetylated hornbeam showed even higher strength and hardness properties than those of acetylated beech and radiata pine. Hornbeam, in its natural form, is a nondurable wood species with a strong, hard, dense, tough and wear-resistant structure. Its sensitivity to moisture and low durability has hindered its use outdoors, but with acetylation it became a denser, less moisture-sensitive, more dimensionally stable and more durable material. In addition to acetylated beech and radiata pine, it could become a raw material for many indoor and outdoor products that are exposed to varying humidity, fungi, and heat load, such as decking, marine decking, fencing, outdoor stairs, furniture, handrails, etc. After these promising research findings, further examinations that will focus on the optimization of the acetylation treatment of hornbeam are planned. In addition, other tests are being considered regarding behavior to other exposures like surface treatability and bonding, and technological properties like corrosion resistance and workability.

\section{Acknowledgements}

We thank Accsys Technologies (Arnhem, the Netherlands) for their cooperation and support in the acetylation process and for sharing their experience and ideas. We also thank the colleagues at the Institute of Wood Science in Sopron (Hungary) who helped during the measurements.

\section{References}

Beckers EPJ, Militz H, Stevens M (1994). Resistance of acetylated wood to basidiomycetes, soft rot and blue stain. Document IRG/WP/9440021, The International Research Group on Wood Preservation, Bali, Indonesia, pp. 11. Bongers HPM, Beckers EPJ (2003). Mechanical properties of acetylated solid wood treated on pilot plant scale. In: Proceedings of the "First European Conference on Wood Modification" (Van Acker J, Hill CAS eds). Ghent (Belgium), 34 April 2003. Ghent, Belgium, pp. 341-350. [online] URL: http://www.researchgate.net/ publication $/ 270042928$

DIN-52182 (1976). Testing of wood; determination of density. German Institute for Standardization, Berlin, Germany, pp. 3.

DIN-52183 (1977). Testing of wood; determination of moisture content. German Institute for Standardization, Berlin, Germany, pp. 4.

DIN-52184 (1979). Testing of wood; determination of swelling and shrinkage. German Institute for Standardization, Berlin, Germany, pp. 4.

DIN-52185 (1976). Testing of wood; compression test parallel to grain. German Institute for Standardization, Berlin, Germany, pp. 4.

DIN-52186 (1978). Testing of wood; bending test. German Institute for Standardization, Berlin, Germany, pp. 4.

DIN-52189-1 (1981). Testing of wood; Impact bending test; Determination of impact bending strength. German Institute for Standardization, Berlin, Germany, pp. 3.

Dreher WA, Goldstein IS, Cramer GR (1964). Mechanical properties of acetylated wood. Forest Products Society 14: 66-68.

EN-113 (1996). Wood preservatives. Test method for determining the protective effectiveness against wood destroying basidiomycetes. Determination of the toxic values. European Committee for Standardization, Brussels, Belgium, pp. 34 .

EN-13183-2 (2002). Moisture content of a piece of sawn timber. Estimation by electrical resistance method. European Committee for Standardization, Brussels, Belgium, pp. 10.

EN-1534 (2010). Wood flooring - Determination of resistance to indentation - Test method. European Committee for Standardization, Brussels, Belgium, pp. 14. 
EN-350 (1994). Durability of wood and woodbased products - Natural durability of solid wood. European Committee for Standardization, Brussels, Belgium, pp. 64.

EN-927-5 (2007). Paints and varnishes - Coating 6 materials and coating system for exterior wood - Part 5: Assessment of the liquid water permeability. European Committee for Standardization, Brussels, Belgium, pp. 22.

Engelund ET, Klamer M, Venås TM (2010). Acquisition of sorption isotherms for modified 2 woods by the use of dynamic vapour sorption instrumentation. Principles and Practice. Document IRG/WP/10-40518, International Research 5 Group on Wood Preservation, Biarritz, France, pp. 10. [online] URL: http://www.cabdirect. org/cabdirect/abstract/20103342064

${ }_{18}^{8}$ Fuchs W (1928). Genuine lignin. I. Acetylation of pine wood. Berichte der Deutschen Chemischen Gesellschaft 61: 948-51. - doi: 10.1002/cber. 19280610512

Hill CAS (2006). Wood modification, chemical thermal and other processes. John Wiley and 4 Sons Ltd, Chichester, UK, pp. 260.

Hill CAS, Hale MD, Farahani MR, Forster S, Suttie ED, Jones D, Papadopoulos AN (2003). Decay of anhydride modified wood. In: Proceedings of the "First European Conference on Wood Modification" (Van Acker J, Hill CAS eds).

30 Ghent (Belgium) 3-4 April 2003. Ghent, Belgium, pp. 143-152. [online] URL: http:// www. researchgate.net/publication/249382983

${ }_{33}$ Hon DNS (1996). Chemical modification of lignocellulosic materials. Marcel Dekker Inc., New York, USA, pp. 384.

${ }^{36}$ Imamura Y, Nishimoto K (1987). Some aspects on resistance of acetylated wood against biodeterioration. Wood Research 74: 33-44.

39 [online] URL: http://repository.kulib.kyoto-u.ac. jp/dspace/handle/2433/53296?locale=en

ISO-3350 (1975). Wood - Determination of static 42 hardness. International Organization for Standardization, Geneva, Switzerland, pp. 24.

Larsson BP, Simonson R (1994). A study of 5 strength, hardness and deformation of acetylated Scandinavian softwoods. Holz als Rohund Werkstoff 52 (2): 83-86. - doi: 10.1007/BF 02615470

Larsson PB, Simonson R, Bergman O, Nilsson T (2000). Resistance of acetylated wood to biological degradation. Holz als Roh- und Werkstoff 58: 331-337. - doi: 10.1007/s001070050439
Larsson P, Tillman AM (1989). Acetylation of lignocellulosic materials. Document IRG/WP/3516, International Research Group on Wood Preservation, Lappeenranta, Finland, pp. 19.

Militz H (1991a). Improvements of stability and durability of beechwood (Fagus sylvatica) by means of treatment with acetic anhydride. Document IRG/WP/3645, International Research Group on Wood Preservation, Kyoto, Japan, pp. 13.

Militz H (1991b). The improvement of dimensional stability and durability of wood through treatment with non-catalysed acetic acid anhydride. Holz als Roh- und Werkstoff 49: 147-152. doi: $10.1007 / B F 02607895$

Molnár S (2004). Faanyagismeret [Wood material science]. Mezogazdasági Szaktudás Kiadó, Budapest, Hungary, pp. 468. [in Hungarian] Molnár S, Bariska M (2002). Wood species of Hungary. Szaktudás Kiadó Ház Zrt, Budapest, Hungary, pp. 212.

Narayanamurti D, Handa BK (1953). Acetylated wood. Das papier 7: 87-92.

Németh R, Gohér G, Hofmann T, Rákosa R (2010). Physical, mechanical and colour properties of acetylated poplar and robinia wood. In: Proceedings of $6^{\text {th }}$ IUFRO Symposium "Wood Structure and Properties 10" (Kúdela J, Lagana R eds). Podbanské (Slovakia) 10 Sept 2010. Arbora Publishers, Zvolen, Czech Republic, pp. 231.

Ohkoshi M, Kato A, Suzuki K, Hayashi N, Ishihara $M$ (1999). Characterization of acetylated wood decayed by brown-rot and white-rot fungi. Journal of Wood Science 45: 69-75. - doi: 10.1007/BF00579526

Ozmen N (2007). Dimensional stabilization of fast growing forest species by acetylation. Journal of Applied Sciences 7: 710-714. - doi: 10.3923/jas.2007.710.714

Papadopoulos AN (2008). The effect of acetylation on bending strength of finger jointed beech wood (Fagus sylvatica L.). Holz als Rohund Werkstoff 66: 309-310. - doi: 10.1007/soo 107-007-0223-3

Papadopoulos AN, Tountziarakis P (2011). The effect of acetylation on the Janka hardness of pine wood. European Journal of Wood and Wood Products 69: 499-500. - doi: 10.1007/soo 107-010-0484-0

Papadopoulos AN, Tountziarakis P (2012). Toughness of pine wood chemically modified with acetic anhydride. European Journal of Wood and Wood Products 70: 399-400. - doi: 10.1007/ s00107-011-0544-0

${ }^{8}$ Peterson MD, Thomas RJ (1978). Protection of wood from decay fungi by acetylation - an ultrastructural and chemical study. Wood and Fiber Science 10: 149-163.

Rafidah KS, Hill CAS, Ormondroyd GA (2006). Dimensional stabilization of rubberwood ( $\mathrm{He}$ vea brasiliensis) with acetic or hexanoic anhydride. Journal of Tropical Forest Science 18: 261268. [online] URL: http://www.jstor.org/stab le/43594684

Ramsden MJ, Blake FSR, Fey NJ (1997). The effect of acetylation on the mechanical properties, hydrophobicity and dimensional stability of Pinus sylvestris. Wood Science and Technology 31: 97-104. - doi: 10.1007/BF00705925

Rowell RM (1983). Chemical modification of wood. Forest Products Abstracts 6: 12 .

Rowell RM (1984). Penetration and reactivity of cell wall components. In: "The Chemistry of Solid Wood" (Rowell RM ed). American Chemical Society, Washington, DC, USA, pp. 175-210. [online] URL: http://pubs.acs.org/doi/abs/10.10 21/ba-1984-0207.choo4

Rowell RM, Plackett DV (1988). Dimensional stability of flakeboards made from acetylated Pinus radiata heartwood or sapwood flakes. New Zealand Journal of Forestry Science 18: 124-131. [online] URL: http://www.scionresear ch.com/_data/assets/pdf_file/0018/30564/NZJ FS1811988ROWELL124_131.pdf

Suttie ED, Hill CAS, Jones D, Orsler RJ (1999). Chemically modified solid wood. I. Resistance to fungal attack. Material und Organismen 32: 159-182.

Van Acker J, De Windt I, Li W, Van Den Bulcke J (2014). Critical parameters on moisture dynamics in relation to time of wetness as factor in service life prediction. Document IRG/WP/1420555, International Research Group on Wood Preservation, St. George, USA, pp. 22.

Wagenführ R (2007). Holzatlas [Wood Atlas]. Fachbuchverlag Leipzig im Carl Hanser Verlag, Germany, pp. 816. [in German]

Youngquist JA, Rowell RM, Krzysik A (1986). Mechanical properties and dimensional stability of acetylated aspen flakeboard. Holz als Roh- und Werkstoff 44: 453-457. - doi: $10.1007 /$ BFo2608064 